\title{
仙台における都心商店街の質的変化
}

\section{桑皿 勝 雄}

はじめに

従来の調査によれば，大都市になると，都心 商店街が，都市発展に半与機能の达大を，通り の伸延といった外㑡への線状の挞張で具現する ことは少なく，多くの場合，買䶮品店舖の集中 度が高まってくる。(杉村 1956，桑島 1963）

しかし，都心商店街における買超品店舗の粠 成此率も，80〜90\% 以上に達すると，その後の 伸び率は停滞し，単に業種構成からだけでは，
その質的変化を考察することはむすかいい。

そこで筆者は，業種構成の考察に加えて，店 舖の规模・形態や売上高などの指標を付加し， 仙台の都心東一番丁通を対象として, 1960・1970 両年次の比敕から，近年における大都市の都心 商店街の変容の傾向を検討した。

なお，調查は主としてアンケート方式を採用 した。回答事はいずれの年放も"90\% を越えた が，両年次の対比の5えで，両年次とも回签し

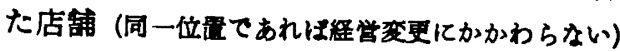

表 I 東一番丁の店舖面稜の爱化

\begin{tabular}{|c|c|c|c|c|c|c|c|c|}
\hline & 年 次 & & 1960 & & & 1970 & & \\
\hline & 項 目 & 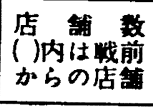 & 店赤の坪数 & 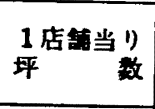 & 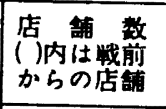 & 店舗の坪数 & 店舗当り & $\begin{array}{l}\text { 增加指 } \\
1960 \text { 数 } \\
=100\end{array}$ \\
\hline & 共 服 ・ 洋 服 & $7(4)$ & 292 & 41 & $7(2)$ & 278 & 39 & 95 \\
\hline & 洋品・衣料品 & $23(11)$ & 684 & 29 & $20(6)$ & 1,384 & 69 & 202 \\
\hline & 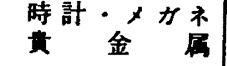 & $7(5)$ & 132 & 18 & $8(5)$ & 227 & 28 & 172 \\
\hline & 阵・はきもの & $8(3)$ & 223 & 15 & $7(2)$ & 245 & 35 & 109 \\
\hline & 楽器・運動具 & $6(4)$ & 108 & 18 & $7(2)$ & 393 & 56 & 363 \\
\hline & カメラ・玩具 & $4(2)$ & 53 & 13 & $5(1)$ & 61 & 12 & 115 \\
\hline & $\begin{array}{ccc}\text { 事 務用 } & \text { 品 } \\
\text { 芸 } & \text { 品 }\end{array}$ & $7(5)$ & 91 & 13 & $7(5)$ & 128 & 18 & 140 \\
\hline & 青耤・雑誌 & $5(2)$ & 555 & 111 & $6(2)$ & 621 & 103 & 110 \\
\hline & 家具·電気用品 & $10(5)$ & 193 & 19 & $10(5)$ & 308 & 30 & 159 \\
\hline & 名産品 & $2(2)$ & 92 & 46 & $2(2)$ & 78 & 39 & 84 \\
\hline & 小＼cjkstart計 & $\begin{array}{r}79(43) \\
(71.8 \%) \\
\end{array}$ & $\begin{array}{c}2,423 \\
(19.6 \%) \\
\end{array}$ & & $\begin{array}{r}79(32) \\
(71.8 \%) \\
\end{array}$ & $\begin{array}{r}3,723 \\
(22.6 \%) \\
\end{array}$ & & 153 \\
\hline & 百华店 & $\begin{array}{c}2(2) \\
(1.8 \%) \\
\end{array}$ & $\begin{array}{r}8,438 \\
(68.4 \%) \\
\end{array}$ & 4,219 & $\begin{array}{r}2(2) \\
(1.8 \% \\
\end{array}$ & $\begin{array}{r}11,060 \\
(67.4 \%) \\
\end{array}$ & 5,530 & 131 \\
\hline 12 & 契茶・食堂 & $7(2)$ & 929 & 132 & $10(1)$ & 1,030 & 103 & 110 \\
\hline 13 & 画 & $1(1)$ & 200 & 200 & $1(1)$ & 200 & 200 & 100 \\
\hline 14 & ハ $千$ ン & 1 & 40 & & 2 & 95 & 47 & 237 \\
\hline & 小 計 & $\begin{array}{r}9(3) \\
(8.2 \%) \\
\end{array}$ & $\begin{array}{l}1,169 \\
(9.4 \%) \\
\end{array}$ & & $\begin{array}{r}13(2) \\
(11.8 \%) \\
\end{array}$ & $\begin{array}{c}1,325 \\
(8.1 \%) \\
\end{array}$ & & 113 \\
\hline & 莧子 · 果物 & 4 & 57 & 14 & 3 & 51 & 13 & 89 \\
\hline & 酒·食肉・鲜魚 & $4(3)$ & 35 & 8 & $4(1)$ & 45 & 11 & 128 \\
\hline 17 & 金物・七トモノ & $8(6)$ & 171 & 21 & $5(3)$ & 176 & 35 & 103 \\
\hline 18 & 藥 & $4(4)$ & 42 & 10 & $4(4)$ & 48 & 12 & 114 \\
\hline & 小 & $\begin{array}{r}20(13) \\
(18.2 \%) \\
\end{array}$ & $\begin{array}{r}305 \\
(2.6 \%) \\
\end{array}$ & & $\begin{array}{r}16(8) \\
(14.6 \%) \\
\end{array}$ & $\begin{array}{r}320 \\
(1.9 \%) \\
\end{array}$ & & 104 \\
\hline & 計 & $\begin{array}{l}110(61) \\
(100 \%)\end{array}$ & $\begin{array}{l}12,335 \\
(100 \%)\end{array}$ & & $\begin{array}{c}110(44) \\
(100 \%)\end{array}$ & $\begin{array}{l}16,428 \\
(100 \%)\end{array}$ & & 133 \\
\hline
\end{tabular}


以外は，集計の際に除外したので，当商店街の全 店舗の $70 \%$ に当る 110 店にとどまっている （ただし，銀行・事務所は1960年 7 社，1970 年には 3 社 てあるが，全部除外した)。

\section{1 空間的拡大}

この 10 年間における東一番丁通の業種構成 についてみると、1953・1962 の両年次の 業種 構成のみの悉皆調査による比較から知れた傾向 と，大同小異である。(桑岛 1964)

つまり，総体的には文化用品，领食・乫茶な どの，とくに都心的性格の強い業種の集中があ り, 徐々ではあるか，商業・サーピス機能を強 化しつつあると理解される。
ところが，店舖規模をみると，この 10 年間に おける売場の著しい桩張が注目される。すなわ ち，表 Iにみられるよらに，買廻品店舖では， 洋品・衣料品, 時計・メガネ・貴金属, 楽器・ 運動具, 家具・電気用品など1)の, 都心的な羓 種といわれる店舗面稳の桩張が明らかである。

次に，商店街の核を形成しているといわれる 百货店については，この期間がすでにその拻張 工事の一段落した後であるので，空間的挾大は 3 割程度である。しかし，商店街の総店舖面稓 (调查対象 110 店舖のみ) に占める比率は大さく， 両年次とも実に $60 \%$ を越えており，店舖面稜 からみた百貨店機能の巨大さが知れる。

また，この間において，戦前からの店舗が年

表 II 東一兴丁の店悀形管・規模の变化

\begin{tabular}{|c|c|c|c|c|c|c|c|c|c|c|c|c|c|c|c|}
\hline \multirow{2}{*}{\multicolumn{2}{|c|}{ 管 }} & \multicolumn{7}{|c|}{1960} & \multicolumn{7}{|c|}{1970} \\
\hline & & \multicolumn{3}{|c|}{ 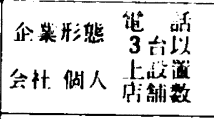 } & \multirow{2}{*}{$\begin{array}{c}\text { 従基 } \\
\text { 数 } \\
84\end{array}$} & 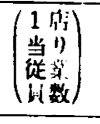 & 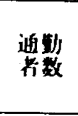 & 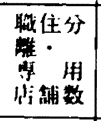 & \multicolumn{2}{|c|}{$\begin{array}{l}\text { 企業形的 } \\
\text { 公外. 湖人 }\end{array}$} & 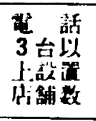 & \multirow{2}{*}{$\begin{array}{l}\begin{array}{l}\text { 従菜 } \\
\text { 引数 }\end{array} \\
272\end{array}$} & 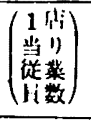 & \multirow{2}{*}{ 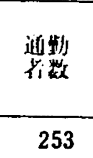 } & \multirow{2}{*}{ 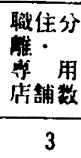 } \\
\hline & 只服 · 浮服 & 7 & 0 & 1 & & (12) & 44 & 4 & 6 & 1 & 1 & & $(38)$ & & \\
\hline 2 & 洋出 ·衣料品 & 15 & 8 & 3 & 362 & (15) & 317 & 13 & 13 & 7 & 3 & 230 & (11) & 215 & 12 \\
\hline 3 & 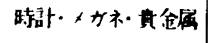 & 2 & 5 & 1 & 88 & (12) & 69 & 4 & 6 & 2 & 2 & 80 & (10) & 73 & 6 \\
\hline 4 & 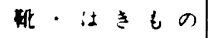 & 7 & 1 & 2 & 80 & (10) & 75 & 5 & 7 & 0 & 1 & 61 & ( 8$)$ & 56 & 6 \\
\hline 5 & 浆染”。連動具 & 5 & 1 & 2 & 83 & (13) & 80 & 5 & 5 & 2 & 3 & 90 & (12) & 90 & 7 \\
\hline & 力 $\Rightarrow$. 玩具 & 3 & 1 & 0 & 23 & ( 5$)$ & 23 & 4 & 4 & 1 & 1 & 45 & ( 9 ) & 45 & 5 \\
\hline 7 & 事稀用该 · 工芸品 & 6 & 1 & 3 & 48 & $(6)$ & 38 & 2 & 6 & 1 & 3 & 87 & (12) & 76 & 5 \\
\hline 8 & 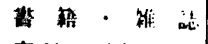 & 4 & 1 & 3 & 170 & (34) & 169 & 5 & 5 & 1 & 3 & 247 & (41) & 246 & 6 \\
\hline 9 & 家其・西公用品 & 7 & 3 & 1 & 117 & (11) & 95 & 4 & 8 & 2 & 2 & 120 & $(12)$ & 104 & 7 \\
\hline \multirow[t]{2}{*}{10} & 名産 & 2 & 0 & 0 & 33 & (16) & 31 & 0 & 2 & 0 & 1 & 40 & $(20)$ & 39 & 0 \\
\hline & ut & 58 & 21 & 16 & $\begin{array}{r}1,088 \\
(46.0 \%) \\
\end{array}$ & & 941 & 46 & 62 & 17 & 20 & $\begin{array}{r}1.272 \\
(40.0 \%) \\
\end{array}$ & & 1,197 & 57 \\
\hline 11 & $\overline{\mathrm{ii}}$ & 2 & 0 & 2 & $\begin{array}{r}758 \\
(32.0 \%) \\
\end{array}$ & (379) & 758 & 2 & 2 & 0 & 2 & $\begin{array}{r}1,376 \\
(43.2 \%) \\
\end{array}$ & $(688)$ & 1,376 & 2 \\
\hline & 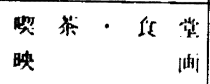 & $\begin{array}{l}3 \\
1\end{array}$ & 4 & 3 & $\begin{array}{r}297 \\
20\end{array}$ & $\begin{array}{l}(42) \\
(20)\end{array}$ & $\begin{array}{r}226 \\
20\end{array}$ & $\begin{array}{l}3 \\
1\end{array}$ & 8 & 3 & 4 & 346 & (31) & 323 & 8 \\
\hline \multirow[t]{2}{*}{14} & 八 $千=$ ב & 1 & & 0 & 15 & (15) & 7 & 1 & 1 & 1 & 0 & 32 & (16) & 32 & 2 \\
\hline & 小 & 5 & 4 & 31 & $\begin{array}{r}332 \\
(14.0 \%) \\
\end{array}$ & & 253 & 5 & 9 & 4 & 4 & $\begin{array}{r}378 \\
(11.8 \%) \\
\end{array}$ & & 355 & 10 \\
\hline 15 & 菓宁果物 & 2 & 2 & 0 & 14 & ( 3 ) & 14 & 4 & 3 & 0 & 0 & 38 & (12) & 38 & 3 \\
\hline & 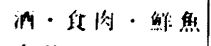 & 3 & 1 & 0 & 26 & (6) & 3 & 1 & 3 & 1 & 1 & 26 & $(6)$ & 5 & 3 \\
\hline 17 & 苗物・セトモノ & 7 & 1 & 1 & 127 & (15) & 100 & 5 & 4 & 1 & 1 & 79 & (15) & 77 & 3 \\
\hline \multirow[t]{3}{*}{18} & 乘 & 3 & 1 & 0 & 20 & ( 5$)$ & 7 & 0 & 2 & 2 & 0 & 18 & (4) & 10 & 0 \\
\hline & 小 & 15 & 5 & 1 & $\begin{array}{r}187 \\
(8.0 \%) \\
\end{array}$ & & 124 & 10 & 12 & 4 & 21 & $\left.\begin{array}{r}161 \\
(5.0 \%\end{array}\right)$ & & 130 & 9 \\
\hline & 全 & 80 & 30 & 22 & 2,365 & & 2,076 & $\begin{array}{c}63 \\
57.2 \% \\
\text { 分離事!) }\end{array}$ & 85 & 25 & 28 & 3,187 & & 3,058 & $\begin{array}{c}78 \\
70.9 \% \\
\text { 分離.4 }\end{array}$ \\
\hline
\end{tabular}

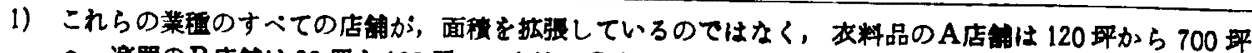

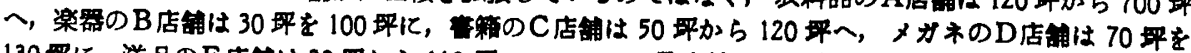

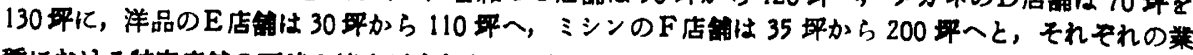

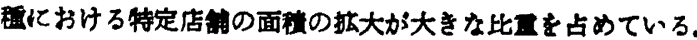


々減少しており，その䅅営者の移動が敏しい。 さらに他方においては，企業形態の変化がみら れ、会社企業は 80 社から85 社に增え, 個人企 業は 30 店から 25 店へと減少している。また， 電話の設置においても，3 台以上を有する店舗 が 22 から 28 に增加している。

\section{2 徉業員数の变化と瞒住分淮}

この 10 年間における東一番丁商店街の機能 の拉大は，一面において店舗面榬の抬張といら 具体的な事実によって把握されるが，次に，释 営規模の桩大とかかわり合いをむつ従業員数に 関し，表IIによって検討してみよら。

さて,一店舖当りの従業員数をみると,店舗面 積の著しい拡大にもかかからず，過半の莱種が 娍少むしくは現状稚持の状態にある。そして， わずかに大規模化をはかった企業の進出が含ま れている吳服・洋服，雑誌・書籍などの部門が 增員している。

しかし，百貨店においては诸しい增員がみら れ，近年における等力去底のなかで，とくに 商店街においては，百貨店に若年学的力が吸叹 されていると考えられる2)。つまり，百貨店は 現在のところ空間的にも，人的にも达大し，そ の機能を強化しつつあるとみられる。

また，释営者を含めた従業員数に占める通勤 者数の割合が增加し，住込及者数が娍少しる，

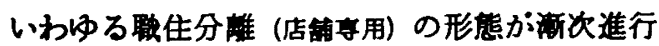
している。とくにこの㑯向は，第 1 図にみられ るよ5に，従業員 15 人以上の店赤に強く，店 铺の規模と娥住分離との相関が密接であるとい えよ5。

この職住分睢の進行を堨所的にみると，主要 通りや大通りと交叉する十字路に店舗専用地区 の広がりがみられ，また，そこには大規模店舗 の進出がみられる。

一方，東一番丁商店街から分嶣した住居は第 2因に示すよ5に，C B D外辺の西部と北東部 に集确地区を形成しているが，この 10 年間に おける住居分布をみると，C B D 外辺部の住居 地区では，住居の变更が市街地周辺部に散在す る住居にくらべて著しく多くなっている。

また, 1960 年以降分離した住居は，市街地周

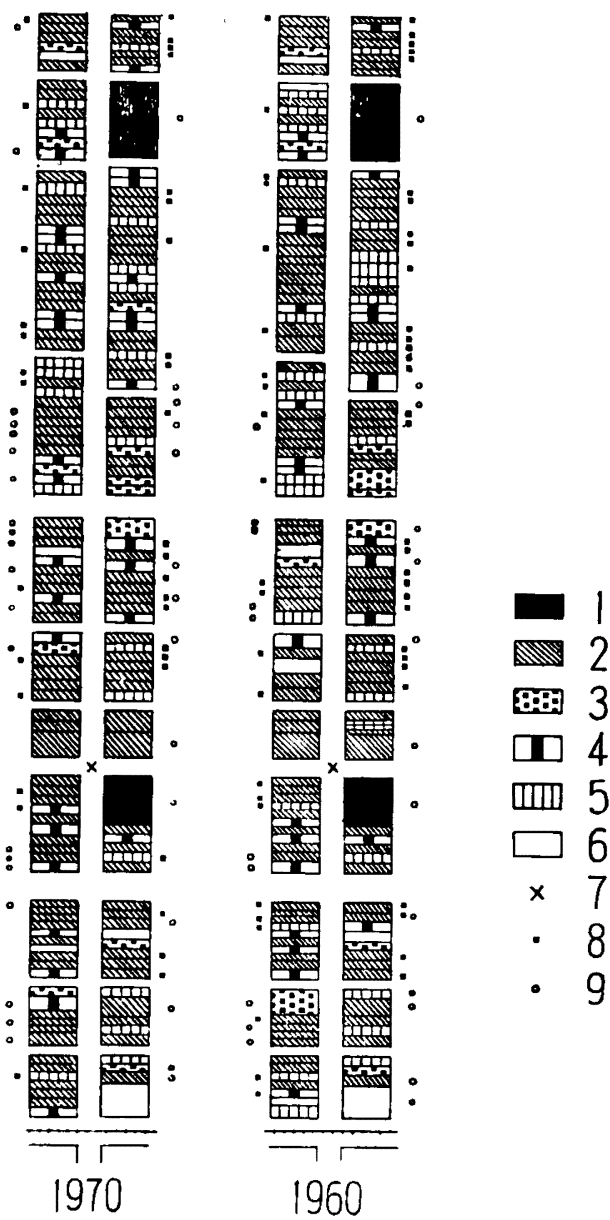

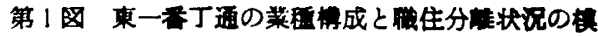
式図（口の囲いは一店解の1階の莱玨を示している がその大きさは，必ずしも店諳面稜に比例しない）

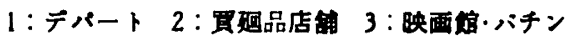

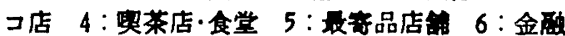

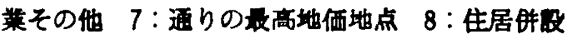
9 : 徒莱 15 员人上上の店㖑 $(8.9$ はいずれる両年 次ともアンケートで回答したもののみ)

辺部に分散しているむのよりも，C B D外辺の 従来の集積地区に近接して，その外側に付加し ている住居が多い。

\section{3 売上高の変化}

売上高の集計については, とくに両年次とも 回答を得た同一の業種・店舖に限り，その伸び 率を検討したので，資料としては抽出調查の籍 囲を出ないが，ある程度都心商店街の一般的傾

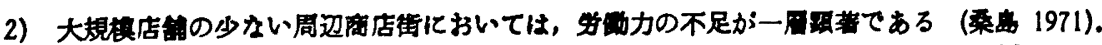

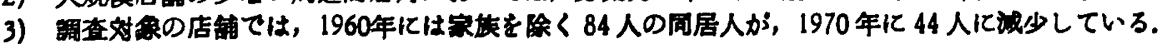


O

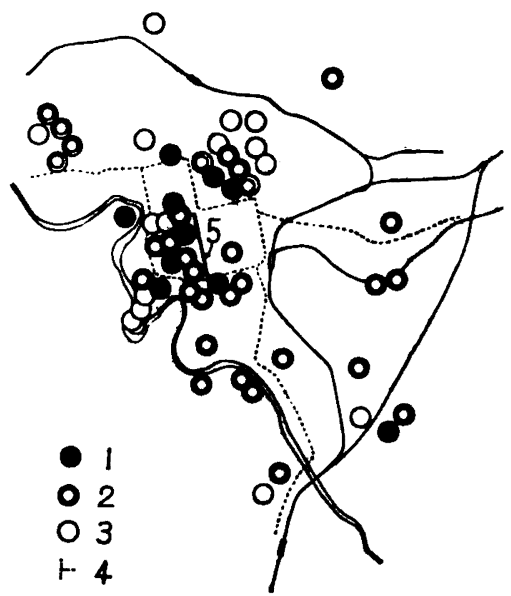

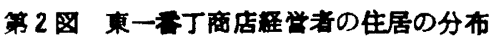

(住居が店盘併設されてないちのて，生居 の位传を明即したるののみ)

1：1960年に存在し，1970年には变更していろ住 居 2：1960年, 1970年の両年次と b交更のない

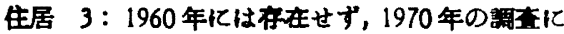

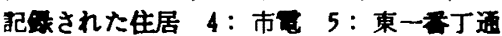

向を推察することができよう。

その一つは，百货店の伸び革が 490 ときわめ て高い数値を示していることである。この年間

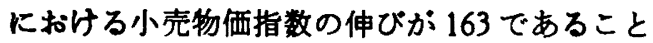
と考え合せると、いかに百货店の売上高か滠䠰 的に上年したかが知れよ5。

また，この尧上高の上年佰向は，䫓面におい

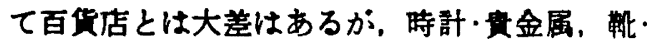

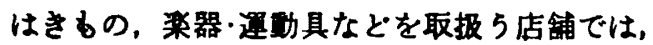
いずれも指数 400 を越え，とくに都心的性格の 強い盛店に現われてくる。

百货店および広城商图をるつ買超品店舗の充

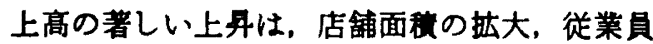
数の增加などの諸現象よりも，さらに都心商店 街の機能の実質的な拡大，その結果としての商 店街の中心性の強化を示すむのと解されよ5。

\section{おわりに}

以上，仙台の都心東一昚丁商店街を対象とし $\tau$,近年 10 年間にみられる商店街内部の变容に ついて考察したか，限られた通りのなかです， 予想以上に店舗の空间的な桩大中，娥住分離か： 進行していることが知れた。

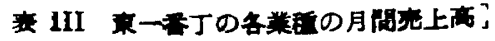

\begin{tabular}{|c|c|c|c|c|}
\hline 項 目 & 回答 & $\begin{array}{l}\text { 一跕誧 } \\
\text { 月学位 }\end{array}$ & $\begin{array}{l}\text { 当尚 } \\
\text { 鬲) }\end{array}$ & 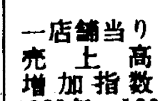 \\
\hline 莱 種 & & 1960 & 1970 & \\
\hline 点服 - 洋 服 & 4 & 285 & 450 & 157 \\
\hline 洋品・衣料品 & 7 & 657 & 1,578 & 240 \\
\hline 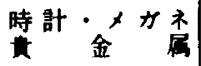 & 2 & 450 & 2,150 & 477 \\
\hline 槿・はもの & 3 & 61 & 250 & 409 \\
\hline 楽器 - 遇的具 & 2 & 275 & 1,500 & 545 \\
\hline カメラ ・ 玩具 & 1 & 100 & 400 & 400 \\
\hline 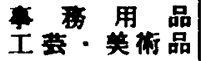 & 4 & 177 & 351 & 141 \\
\hline 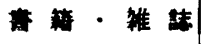 & 1 & 1,500 & 4,000 & 266 \\
\hline 家具・正気用品 & 5 & 334 & 578 & 173 \\
\hline 多座品 & 1 & 450 & 1,000 & 222 \\
\hline 均 & & 393 & 1,019 & 259 \\
\hline 百监 店 & 2 & 16,000 & 79.500 & 490 \\
\hline 相・肉・鲜魚 & 2 & 190 & 250 & 131 \\
\hline $\begin{array}{l}\text { 金物 - } \\
\text { 維 }\end{array}$ & 5 & 170 & 520 & 305 \\
\hline$<\quad t$ & 3 & 106 & 180 & 169 \\
\hline 均 & & 154 & 364 & 236 \\
\hline
\end{tabular}

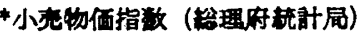

1960 年 $=100 ， 1970$ 年 $=163(5$ 万以上の都市を 対会とする)

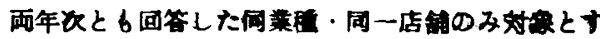
了

また，これらの蔽現争が，都心的性格のとく

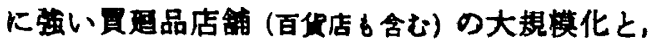
商品壳上高の上丹と年接に関連しており，加之 て奧莱店などの著しい進出から，東一番丁商店

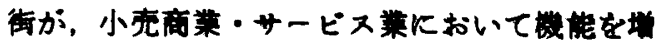
強していることが明らかにされた。

しかし，ここで道用した分析指票が音週的な ののになるためには，さらに他都市之の比較研 宽がナすめられねばならない。

(1971. 8. 30 兴理)

\section{文背}

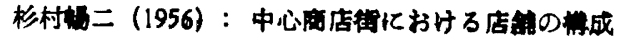
之国增 地理评 29 550 558

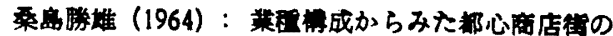
発屈通程 地理平 39 649 660

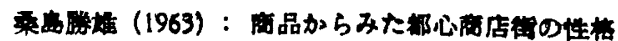
束北地理 $15 \quad 7 \sim 11$

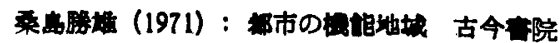




\section{Change of Characters of the Central Shopping Street in Sendai}

\section{Katsuo KUWAJIMA}

The writer investigated the central shopping street, Higashi-ichi-bancho in Sendai on the items shown in the Tables I-III in 1960 and 1970.

The results gained are as follows:

1. Two department stores in the shopping street have large floor space and it enlarged considerably. Its ratio to that of other shops is more than $70 \%$ always.

The floor spaces of retail shops which mainly deal such expensive goods as clothing. personal ornaments, play-things, furnitures and books have enlarged, too.

2. So far as the number of employees is concerned, it is increasing a little in big shops, but is decreasing or equal in small shops these ten years.

3. Separation of shop and residence is going on through the shopping street, which is remarkable at the crossroads with three main streets.

4. The total sale of the two department stores have extremely increased. And that of retail shops dealing mainly expensive goods is increasing too, but it does not come up to that of the department stores.

5. Generally, cultural and expensive good stores and coffee shops have a tendency to be centralized, but the function of retail service in the central shopping street is gradually expanding. 